\title{
Very large hail occurrence in Poland from 2007 to 2015
}

\author{
Wojciech Pilorz \\ Faculty of Earth Sciences, University of Silesia, 60 Bedzinska Str, 41-200 Sosnowiec, Poland; \\ wojciech.pilorz@gmail.com
}

Received: $27^{\text {th }}$ October, 2015

Accepted: $7^{\text {th }}$ December, 2015

\begin{abstract}
Very large hail is known as a presence of a hailstone greater or equal to $5 \mathrm{~cm}$ in diameter. This phenomenon is rare but its significant consequences, not only to agriculture but also to automobiles, households and people outdoor makes it essential thing to examine. Hail appearance is strictly connected with storms frequency and its kind. The most hail-endangered kind of storm is supercell storm. Geographical distribution of hailstorms was compared with geographical distribution of storms in Poland. Similarities were found. The area of the largest number of storms is southeastern Poland. Analyzed European Severe Weather Database (ESWD) data showed that most of very large hail reports occurred in this part of Poland. The probable reason for this situation is the longest period of lasting tropical airmasses in southeastern Poland. Spatial distribution analysis shows also more hail incidents over Upper Silesia, Lesser Poland, Subcarpathia and Świętokrzyskie regions. The information source about hail occurrence was ESWD - open database, where everyone can add report and find reports which meet given search criteria. 69 hailstorms in the period of 2007 - 2015 were examined. They caused 121 very large hail reports. It was found that there is large disproportion in number of hailstorms and hail reports between individual years. Very large hail season in Poland begins in May and ends in September with cumulation in July. Most of hail occurs between 12:00 and 17:00 UTC, but there were some cases of very large (one extremely large) hail at night and early morning hours. However very large hail is a spectacular phenomenon, its local character determines potentially high information loss rate and it is the most significant problem in hail research.
\end{abstract}

Key words: very large hail, hailstorm, geographical distribution of hail, ESWD data, Poland

\section{Introduction}

On account of its severity to crops, severe hailstorms have been reviewed for more than 150 years. Twardosz et al. (2010) described the first Polish studies of hail. First, simple descriptions of places where hail occurred was made by: Sapalski (1852), Karliński (18671875 ) and Wierzbicki (1876-1901). Later some wider studies of hail occurrence were originated by Wierzbicki (1886), Szulc (1901) and Leja (1929). The complex studies of hail occurrence in Poland was made by Gumiński (1930) and later by Koźmiński (1963) - they pointed regions with the most frequent hail falls (Twardosz et al. 2010). Time variabilities in hail occurrence in Warsaw were reviewed by
Merecki (1915). The interesting study about connections between land use and hail frequency was made by Zinkiewicz and Michna (1955).

In the last few years interest of the phenomena connected with Deep Moist Convection (e.g. hail) has raised and some valuable studies of hail occurrence has been made. Special kind of storm - supercell storm is capable of producing particularly large hail due to favorable hail creation mechanisms within supercells, especially the presence of a strong updraft called mesocyclone, which provides numerous hail circulations (Knight and Knight 2001). Supercell storm is defined by presence of a deep and persistent, rotating updraft called a mesocyclone (Weisman and 
Klemp 1984). This kind of storm was described by Browning (1964). Supercell storms can produce also other threats as tornadoes, damaging, straightline wind gusts and torrential rainfalls (Doswell 2001). That is why it should be taken into account while warning, especially about hail. It was found that great majority of very large hail in Poland during analyzed period caused supercell storms (Pilorz 2015).

Kłokowska and Lorenc (2012) analyzed spatial and yearly distribution of hail. They based on information from 24 thousands "hail questionnaires" - the special form of reporting hail, sending by terrain observers to Polish Institute of Meteorology and Water Management (IMGW). Three hail regions were divided within Polish territory: $1^{\text {st }} \quad$ southeastern, $2^{\text {nd }}$-southwestern and the $3^{\text {rd }}-$ internal (Fig. 1). As the most frequently hail observed region, the most clearly divided and the largest one, the first hail region was pointed. It contains the following regions: Subcarpathia, Upper Silesia, Lesser Poland, Świętokrzyskie, Lubelskie and Mazovia regions. In all mentioned hail regions, hail occurrence is higher than in other areas. Authors also noted decreasing trend of number of hail cases and hail days during analyzed period (1960 - 1978). The highest number of hail days is related to May (23), then June (22 days) and July (21 days). The analysis of later data (1970 - 1980 and 2000 - 2010), from central historical database, shows significant decrease of hail days during the period from April to September (Kłokowska and Lorenc 2012).

Another approach presents the study carried out by Taszarek and Suwała (2015). They made a study of hail in Poland in 2012, containing the analysis of hail diameter, hail spatial distribution and hail occurrence conditions. The study is limited to large hail (hailstones greater or equal to $2 \mathrm{~cm}$ in diameter). They found 121 large hail cases during 26 large hail days in 2012. This one-year study does not represent such spatial regularities as seen by Kłokowska and Lorenc (2012), but shows that most of large hail reports concentrate in southern and eastern Poland. Authors also noted that larger hail occurs less frequently than smaller does.
According to their study, hail falls most frequently between 15:00 and 18:00 UTC. In 2012 domination in hail cases in July was found (Taszarek and Suwała 2015). Since southeastern regions are more likely to produce more very large hail, it is necessary to analyze thunderstorms spatial distribution in Poland to find its similarities. Such research was carried out by Bielec-Bąkowska (2002). The base period was 1949 - 1998. Number of days with thunderstorms increases from northwestern Poland (15,4 days at Świnoujście station) to southeastern part of Poland (34,4 days at Lesko station) - Fig. 2 (Bielec-Bąkowska 2002). The author also analyzed hail days at 23 stations and found similarity in spatial distribution of hail days and days with storm (Bielec-Bąkowska 2013).

There are many possible data sources of hail falls. Vinet (2001), Hohl et al. (2002a) and Changnon (1999) used insurance data (among other data) to determine places with destructive hail falls. Vinet (2001) and Sioutas et al. (2009) used hailpads in their studies. Zhang et al. (2008), Kłokowska and Lorenc (2012), Twardosz et al. (2010), Bielec - Bąkowska (2013), Changnon (1999) used data from meteorological stations as a source of information of hail falls. Some indirect methods of previous hail falls estimation were also applied. Hohl et al. (2002b) used dendrological data to determine the most destructive hail incidents in central Switzerland, Punge et al. (2014) used satellite data to detect the presence of overshooting tops as an indicator of hail while Skripniková and Řezáčová (2014) used multiple radar reflectivity and sounding - based „combi-criterion” to estimate previous hail incidents. This criterion is based on some previously described by other authors criteria which had the best results in testing.

The goal of the study is to present spatial, yearly and diurnal distribution of the most destructive hail incidents (very large hail falls) in Poland from new data source - European Severe Weather Database (ESWD) and compare them to the previous studies based on the different data sources, different periods and size criteria. 


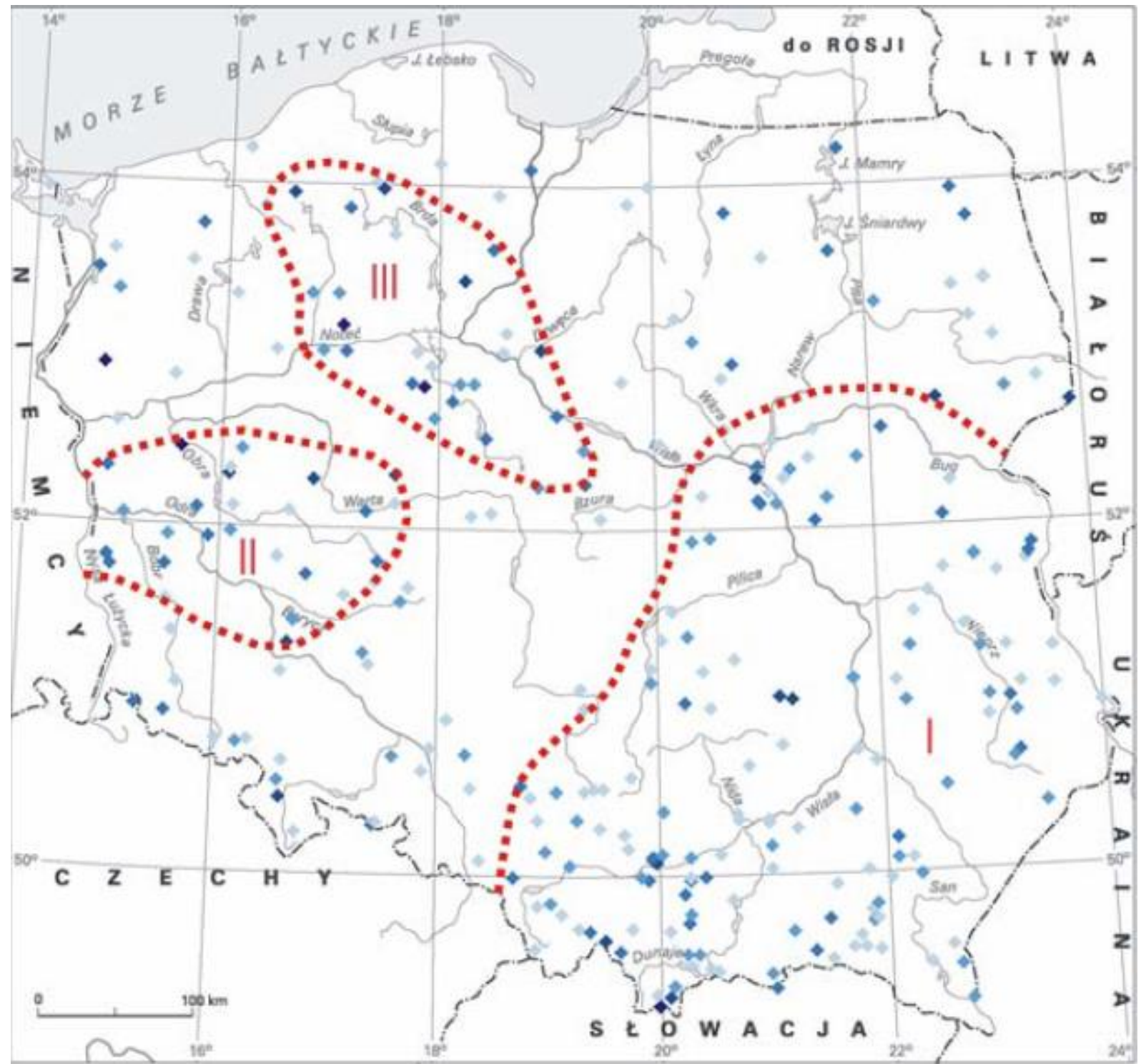

Fig.1. Hail cases in Poland. Color intensity represents number of hail falls from 5 (pale blue) to 16 (dark blue) at each point. Dashed red line shows the regions with the most frequent hail falls which was proposed by Kłokowska and Lorenc (2012). Source: Kłokowska and Lorenc (2012)

\section{Methods and data}

This study is based on the ESWD (Dotzek et al. 2009) data. This database collects reports about severe meteorological phenomena such as: damaging lightnings, heavy rain, large hail, severe wind gusts, tornadoes, gustnadoes, funnel clouds, ice accumulations, heavy snowfall, avalanches and dust devils. ESWD is an open database available via eswd.eu website. Everyone can get data from ESWD, but also everyone can add data to it. Any newly added report needs to be quality passed by ESWD management or cooperative institutions. It proves elimination of incorrect reports added by inexperienced people. Each report has its quality control (QC) mark. There are 4 possible marks: QC 0 - as received, QC 0+ - plausibility check passed, QC 1 - report confirmed and QC 2 - report fully verified. After adding by other people beyond ESWD management and cooperative institutions, every report has QC 0 category, until verification, when it gets higher category. Categories QC 0+ and QC 1 can be added by Skywarn associations, also cooperating with ESWD; QC 2 category can only be added by ESWD management and cooperating with ESWD national 


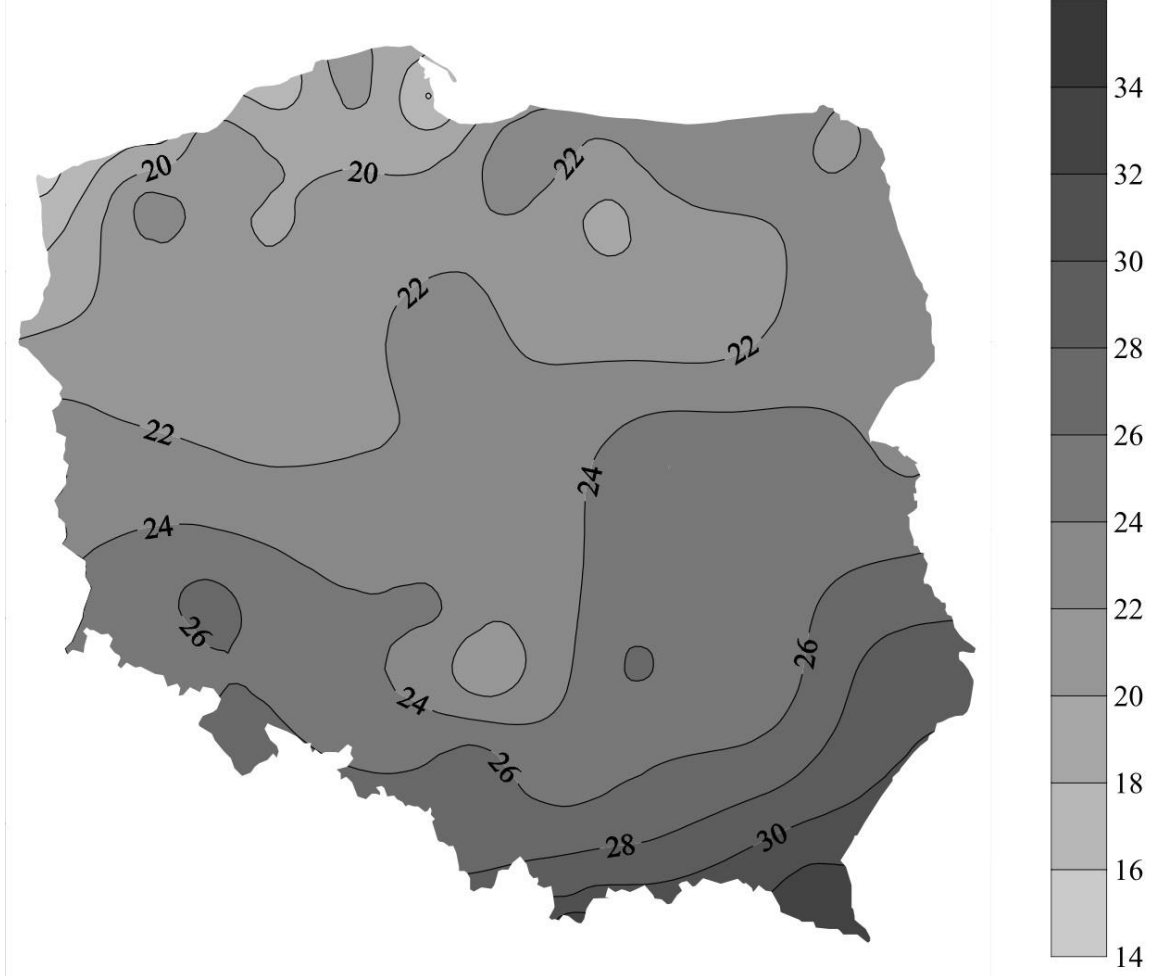

Fig.2. Annual number of days with thunderstorm in Poland in the period of 1949 to 1998. Source: Bielec Bąkowska (2002)

meteorological institutes from any country. Reports with QC 0 category were excluded from this examination.

Hail is defined as a drop of ice crystals with maximum diameter at least $0,5 \mathrm{~cm}$. Large hail is defined by its maximum diameter at least $2 \mathrm{~cm}$. This diameter criterion was accepted by ESWD as a threshold diameter of hail reporting to ESWD. Very large hail is a drop of hailstones with maximum diameter $\geq 5 \mathrm{~cm}$ and extremely large hail is a drop of hailstones with maximum diameter greater or equal to $7,5 \mathrm{~cm}$. In this study the following data were used: coordinates of each very large hail report, a time of hail fall and a size of the largest hailstone. Reports of the hail diameter smaller than $5 \mathrm{~cm}$ were not examined.

Hail spatial distribution maps were carried out in Surfer program. Distinguishing incidents within hail reports was made through radar reflectivity analysis. All very large hail reports caused by a given storm were counted into one hail incident (hailstorm). Coordinates of the largest reported hailstone within the given incident were taken into consideration. The area of the largest number of hailstorms denotes the most hail endangered region.

This study is based on ESWD data from 2007 to 2015. The previous studies which results from this study are compared with are four studies of hail in Poland. Study based also on ESWD data was made by Taszarek and Suwała (2015). They took into consideration all large hail reports (at least $2 \mathrm{~cm}$ in diameter), only from 2012. Hail questionnaires data were used by Kłokowska and Lorenc (2012) as a data source of their investigation, where they analyzed all hail diameter occurrence (all ice crystals greater or equal to $0,5 \mathrm{~cm}$ ) between 1960 and 1978. Bielec-Bąkowska (2013) analyzed all hail falls based on 24 meteorological stations from 1966 to 2006. Twardosz et al. (2010) investigated hail occurrence in Cracow station located in botanical garden from 1863 to 2008 .

Spatial distribution of very large hail is of great importance in estimating the most endangered regions. This data can be useful to insurance companies and the government while spatial planning or modeling agriculture policy. 


\section{Geographical hail distribution}

In the period of 2007 - 2015, ESWD collected 121 very large hail reports from Poland. After radar reflectivity analysis, 69 incidents (hailstorms) were isolated. It means that usually one hailstorm should cause less than two very large hail reports. Actually, great majority of incidents includes only one very large hail report but there were 8 hailstorms which generated four or more $5 \mathrm{~cm}$ plus reports. From the record hailstorm, from June 18, 2013, 8 reports of hail equal to or greater than $5 \mathrm{~cm}$ were reported. The largest hailstone of that storm was $9,5 \mathrm{~cm}$ in diameter. The largest hailstone of 10 $\mathrm{cm}$ in diameter reported three times - in July 2007, in August 2008 and in June 2010. 56,5\% of all examined incidents involved hailstones from 5 to $6 \mathrm{~cm}$ in diameter and only $8,7 \%$ of the analyzed incidents involved hailstones greater or equal to $7,5 \mathrm{~cm}$ which meet extremely large hail criterion.

As seen on the Fig. 3, the highest hail incidents concentration appears in southeastern Poland (Silesian, Lesser Poland, Subcarpathian, Świętokrzyskie, Lubelskie and partly Mazovian regions). From 2 to 5 reports were also noted in Opolskie, Podlaskie, Łódzkie, West Pomeranian, Warmian - Masurian and Lower Silesian regions. One or no hailstorms were noted only in Kuyavian - Pomeranian, Greater Poland, Pomeranian and Lubusz regions. Estimated hail reports distribution (Fig. 3) makes reference to the previous studies of hail (Fig. 1) by Kłokowska and Lorenc (2012) and storm days (Fig. 2) by Bielec-Bąkowska (2002). Their research was made by using different data sources and analyzed different time periods. This examination and the study by Kłokowska and Lorenc (2012) confirms that southeast part of Poland is the most hail endangered. Relevant differences are not clearly visible in two smaller hail regions (central and southwestern) defined by Kłokowska and Lorenc (2012). In these regions some very large hail was reported but it does not represent greater density of its occurrence. The city of Rybnik is worth mentioning. In the neighborhood almost every year or every two years large or very large hail drops which is usually caused by a supercell storm. $5 \mathrm{~cm}$ hail fell in this area in 2007, 2011, 2012 and 2013. What is more, large (but not very large) hailstones were noted there in other terms e.g. in June 2015 when hailstones reached $4 \mathrm{~cm}$. All hailstorms with extremely large hailstones (6 cases) existed only in the southeastern sector of Poland (Fig. 3)

\section{Multiannual, monthly and very large hail diurnal distribution}

Hail is an incidental phenomenon. It needs strictly defined convective conditions to come into being. That is the reason of its high variability from year to year. Large number of hail events in a given year occurs during oneday or several-days incidents of inflow on Polish territory warm and moist, unstable air mass. During such inflow many severe storms usually occur; a few of them usually produce very large hail. When in the given year there are more such inflows, more hailstorms occur. When during the year there is only one or no inflows with enough sufficient conditions to form severe hailstorm, the number of them is strongly limited. One, long lasting inflow of strongly predisposed of hail conditions can provide more hailstorms than hail incidents from other few years counted together, when airmass properties were not sufficient enough to form such high number of hailstorms.

Annual and daily progress of hail fall is strongly correlated with the updraft strength, strong enough to provide numerous hail cycles, which results the large diameter of hail at the ground. Such conditions appear in summer, when air is warm and moist enough to form strong updrafts within convective storms. Therefore most of storms with very large hail falls occur in the warm part of the year in the late afternoon and early evening hours, when after the day's insolation air has the best properties (high temperature and humidity) to raise strongly in the convection process.

Strong variability of number of hailstorms between individual years in Poland was noted by Twardosz et al. (2010), Kłokowska and Lorenc (2012) and Bielec-Bąkowska (2013). 


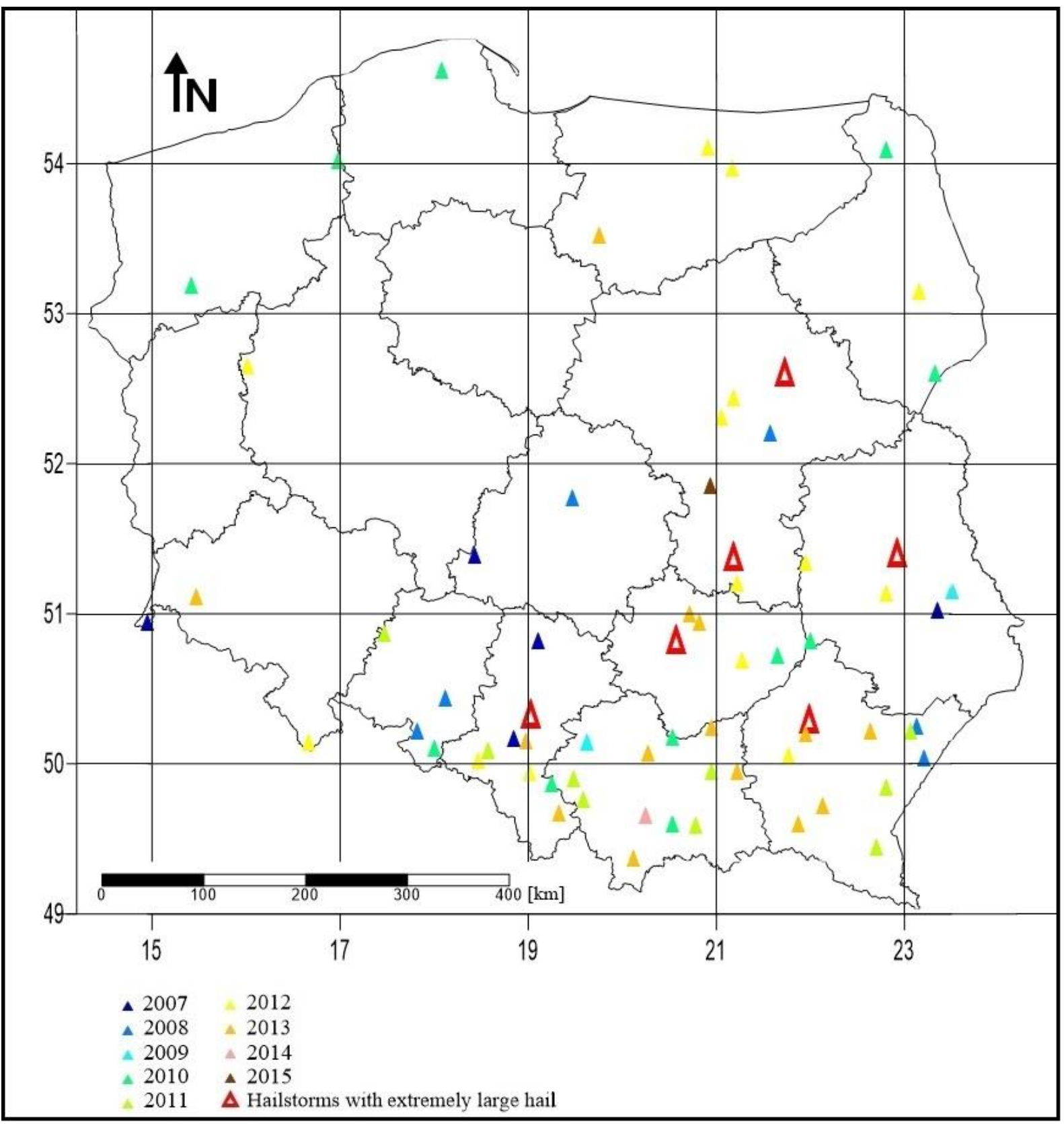

Fig.3. Geographical distribution of very large hail incidents in Poland. Color scale indicates the year of the hailstorm occurrence. The red, enlarged signature indicates hailstorms with extremely large hail. Based on the 2007 - 2015 ESWD reports.

This feature has also been found in this examination. 15 hailstorms (with very large hail) were observed in 2013 while in 2014 and 2015 only one occurred in each of these years in Poland (Fig. 4). In other years, strong variability can also be found. Years: 2010, 2011, 2012 and 2013 can be admittedly named as the high very large hail activity period. In 2007 and 2008 the number of hailstorms was temperate. Apart from conditions variability, the large differences between individual years can also be a result of large hail occurrence in uninhabited area where nobody is able to report the hail presence. 


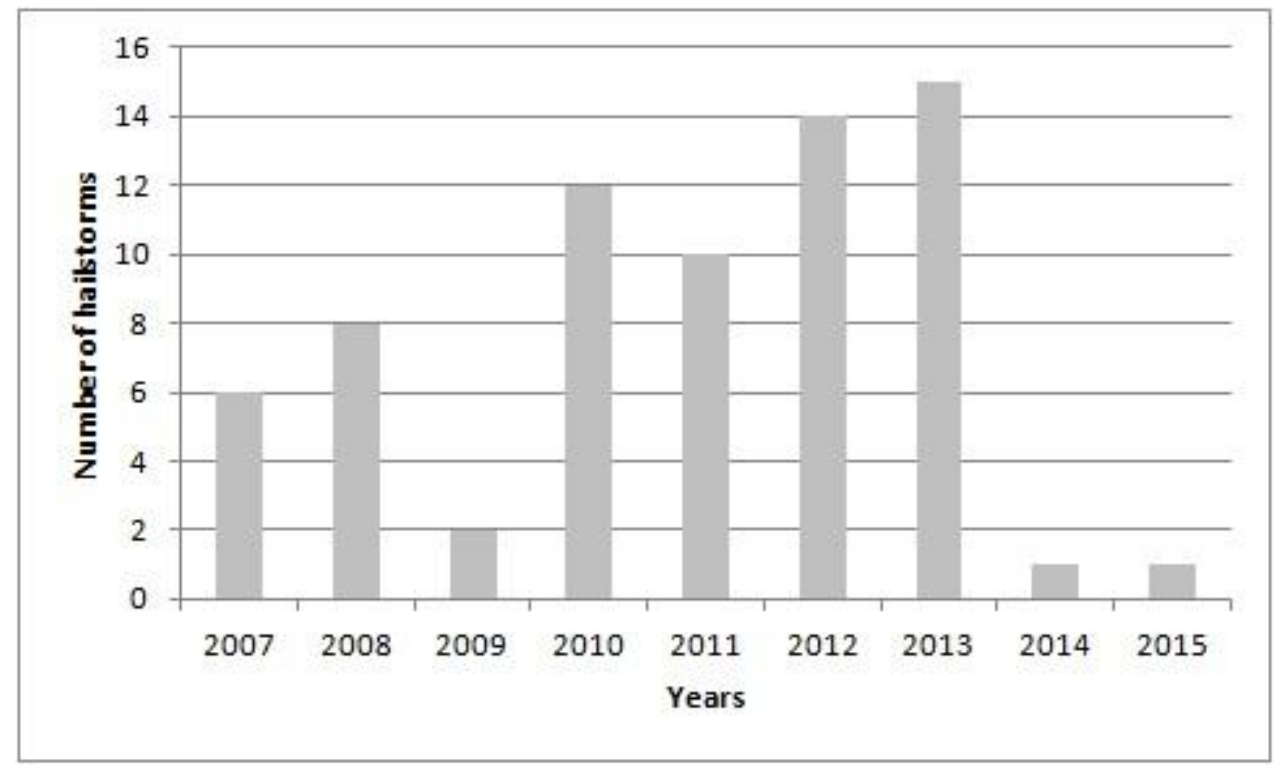

Fig.4. Number of hailstorms in 2007 - 2015 period. Based on ESWD data

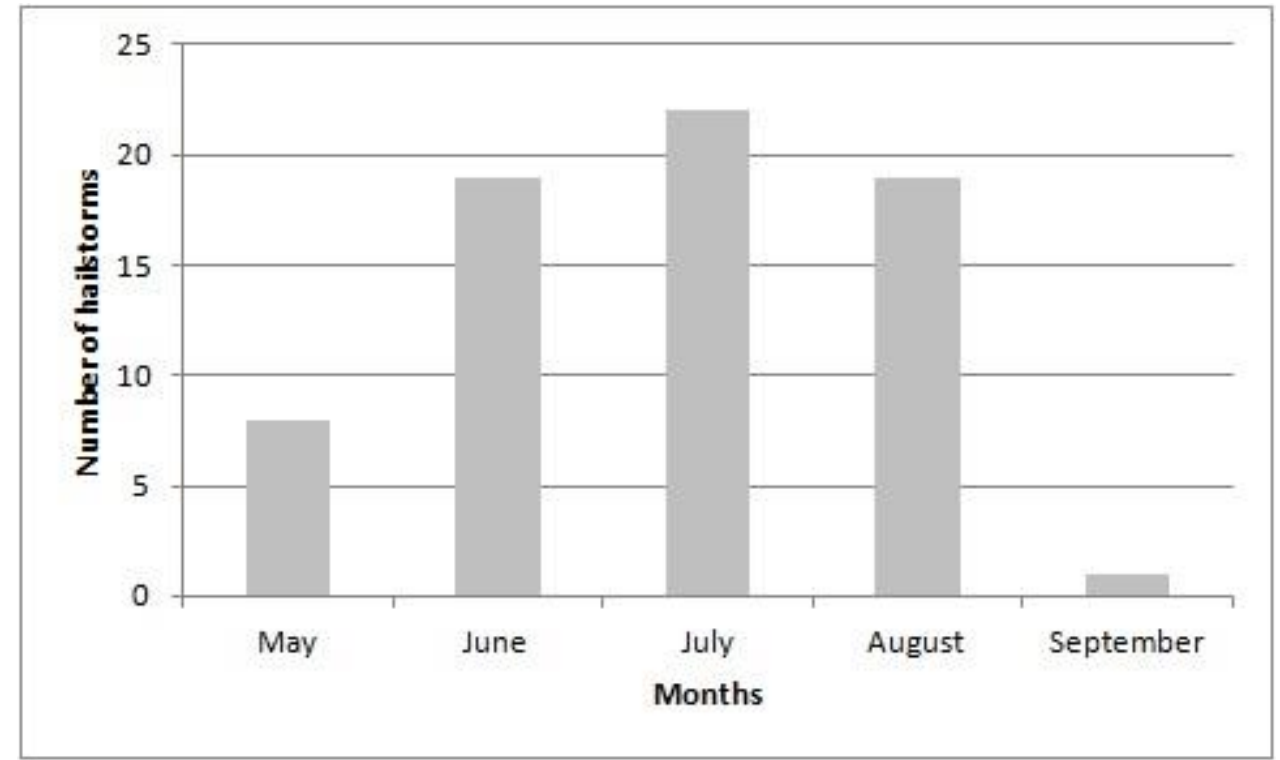

Fig.5. Large hail observed month by month in Poland in 2007 - 2015 period. Based on ESWD data

Hail appearance during the year have been reviewed by numerous authors (e.g. Taszarek and Suwała (2015) and Bielec-Bąkowska (2013) in Poland, Zhang et al. (2008) in China, Sioutas et al. (2009) in Greece and Schuster et al. (2005) in southeastern sector of Australia). Each of these studies conclude that hail occurrence has its maximum in the warm season with some small variabilities caused by local climate factors. Distribution of hail days during the year can vary within different regions (Bielec-Bąkowska 2013, Zhang et al. 2008). Results of ESWD data analysis is in close relationship with previous studies. All reports with hail greater or equal to $5 \mathrm{~cm}$ in the period of $2007-2015$ was from $3^{\text {rd }}$ of May to $5^{\text {th }}$ of September with slight maximum in July (Fig. 5). In June, July and August, $87 \%$ of hailstorms meeting very large hail size criterion took place. In comparison with study by Kłokowska and Lorenc (2012) containing analysis of all hailstones (including small hail), monthly maximum occurrence of hail which meet "very large" criterion is displaced in time from May (all hail maximum) to July. The highest activity of large hail in 2012 (larger or equal to $2 \mathrm{~cm}$ ) 
was obtained in July by Taszarek and Suwała (2015).

Time of hail fall was estimated using radar data. The moment of the storm radar reflectivity (from the lowest elevation) approach at the coordinates of hail fall taken from the ESWD indicates the time of hail occurrence. This method allows to avoid time estimating mistakes usually present in the ESWD. In seven cases, it was not clear which storm caused hail or radar data were unavailable. In those cases, the incident time was taken from the ESWD.

Great majority of hail falls occur in the afternoon and evening hours. Between 12:00 UTC and 17:00 UTC 74\% reported hailstorms occurred (Fig. 6). The highest number of hailstorms occurred between 16:00 UTC and 17:00 UTC. This outcome meets result estimated by Taszarek and Suwała (2015) based on 2012 large hail study, using ESWD data. They find that hail greater or equal to $4 \mathrm{~cm}$ in diameter occurs mostly between the same hours, while smaller hail $(2-4 \mathrm{~cm}$ in diameter) has its maximum occurrence earlier. An interesting result was found during the examination of night and morning hailstorms, when the convection is generally weaker. Eight such hailstorms were found. Some of them occurred in the late morning hours, but three happened at night and early morning time (from midnight to 6 a.m. UTC). The storm from August 15, 2008 needs to be stood out. Maximum hail with diameter of $8,5 \mathrm{~cm}$ reported from Siemianowice Śląskie and Czeladź at 4:30 UTC (6:30 local time). Distinctive radar reflectivity signatures showing the storm severity were visible within that storm.

\section{Very large hail distribution by size}

The most frequent hail meeting "very large" criterion is the smallest hail with diameter of 5 to $5,9 \mathrm{~cm}$ (Fig. 7). Taszarek and Suwała (2015) came to the same conclusion. The second frequency group is hail from 6 to $6,9 \mathrm{~cm}$. These two size groups represents $84 \%$ of all hailstorms. The third hailstone size group is $7-$ $7,9 \mathrm{~cm}$, which represents only $7 \%$ of all hailstorms. The fact which is worth mentioning is that the group of hailstorms with $9-10 \mathrm{~cm}$ hailstones is of higher percentage than the one with $8-8,9 \mathrm{~cm}$ (Fig.7). The rule of the greatest frequency of smaller hail appears not only in very large or large hail size group, but in all size groups of hail, including small hail $(0,5-2 \mathrm{~cm})$ (Sioutas et al. 2009).

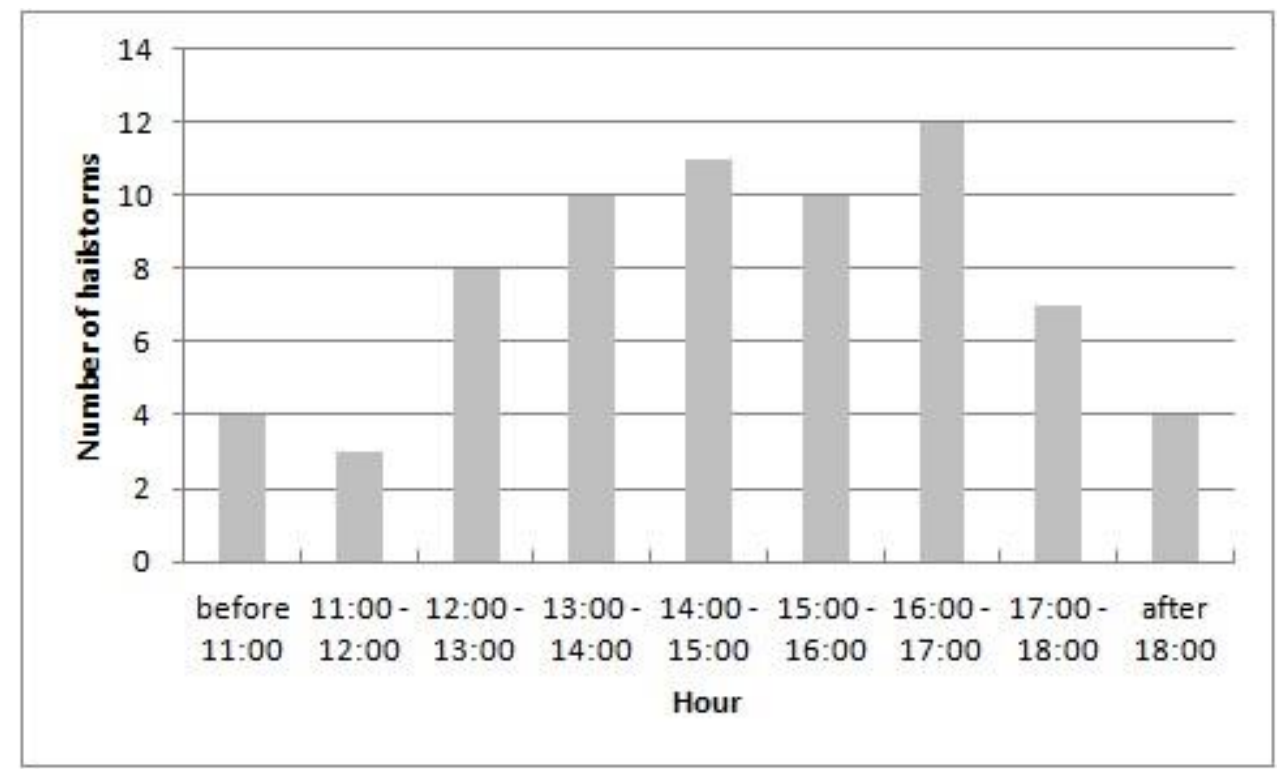

Fig.6. Diurnal very large hail distribution in Poland in 2007 - 2015 period. Times in UTC. Based on radar and ESWD data 


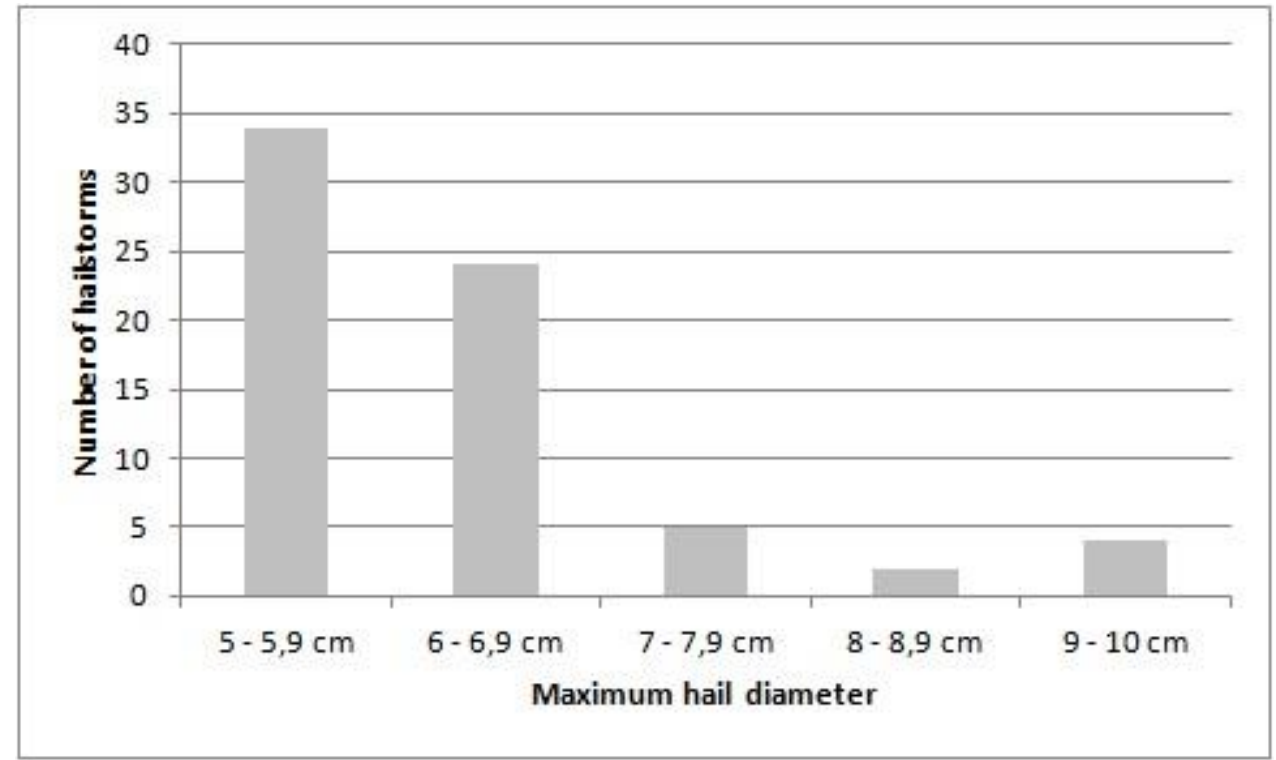

Fig.7. Large hail observed in Poland in 2007 - 2015 period by diameter. Based on ESWD data

\section{Conclusions}

After ESWD data analysis of spatial, diurnal and yearly hail distribution, there are the following conclusions:

a) Spatial distribution of hail reports presents obvious very large hail concentration in southeastern Poland. Probably the reason for such progress is the longest lasting of warm and moist air masses in this part of Poland, which leads to more days with storm and more hailstorms. Previous studies pointed the same region as the highest hail occurrence. On the other hand, there is also one clearly visible sector containing mainly western and partly central Poland with uncommonly very large hail occurrence. In northern part of Poland very large hail occurs rarely. Very large hail and thunderstorms present similar geographical distribution in Poland.

b) Yearly distribution of very large hail presents its concentration in the warm season (from early May to early September), with maximum in July (slightly lower number of hailstorms in June and August). The previous studies as a maximum of hail occurrence pointed May (all hail sizes) and July (large hail).

c) Strong variability of hailstorms number between individual years is observed. The reason for that is incidental character of hail phenomenon, determined by strictly defined atmospheric conditions. On average 7,7 hailstorms with 13,4 very large hail reports occur in Poland each year. Extremely large hail exists on average twice every three years. The greater the hail diameter is, the less often it occurs.

d) Distribution of hail during the day presents strong concentration of hail falls (84\%) in the afternoon and early evening hours (12:00 - 18:00 UTC). Study of hail reports in 2012 states greater concentration of large hail reports (between 15:00 UTC and 18:00 UTC).

Future works must concentrate on increasing hail detection and hail warning techniques, especially by radar. Warning is easier and cheaper now because the only thing needed to reach the majority of the population is simple phone application. It is also important to prove better information system about hail falls on the ground, to be able to verify potential warnings. It can be based on hail questionnaires or hailpad network.

\section{Acknowledgements}

The author is grateful to all people supporting ESWD by adding and verifying large hail reports. Special thanks to $\mathrm{Dr}$ hab. Ewa Łupikasza (University of Silesia) and Igor Laskowski (Skywarn Poland) for essential 
number of advice. Supportive and useful comments by reviewers are also appreciated.

\section{References}

Bielec-Bąkowska Z. (2002): Spatial diversity and long-term variability of thunderstorms in Poland (1949 - 1998) (Zróżnicowanie przestrzenne i zmienność wieloletnia występowania burz w Polsce (1949 1998)). Wydawnictwo Uniwersytetu Śląskiego (in Polish).

Bielec-Bąkowska Z. (2013) Storms and hails in Poland (Burze i grady w Polsce). Prace Geograficzne UJ. 132, 99 - 132 (in Polish), DOI: 10.4467/20833113PG.13.005.1095

Browning K. A. (1964) Airflow and precipitation trajectories within severe local storms which travel to the right of the winds. Journal of the Atmospheric Sciences. 21, $664-668$.

Changnon S. A. (1999) Data and approaches for determining hail risk in the contiguous United States. Journal of Applied Meteorology. 38, 1730 - 1739.

Doswell C. A. (2001) Severe Convective Storms - An Overview. [In:] Severe Convective Storms (ed. C.A. Doswell). American Meteorological Society, Boston, $1-26$.

Dotzek N., Groenemeijer P., Feuerstein B., Holzer A. M. (2009) Overview of ESSL's severe convective storms research using the European Severe Weather Database ESWD. Atmospheric Research. 93, 575 - 586, DOI:10.1016/j.atmosres.2008.10.020

Hohl R., Schiesser H-H., Knepper I. (2002a) The use of weather radars to estimate hail damageto automobiles: an exploratory study in Switzerland. Atmospheric Research. 61, 215 - 238.

Hohl R., Schweingruber F.H., Schiesser H.-H. (2002b) Reconstruction of severe hailstorm occurrence with tree rings: a case study in central Switzerland. Tree-ring Research. 58 (1/2), 11-22.
Kłokowska K., Lorenc H. (2012) Risk of hail apperance in Poland (Ryzyko występowania gradu w Polsce). [In:] Natural disaster and internal country safety (Klęski żywiołowe a bezpieczeństwo wewnętrzne kraju) (ed. H. Lorenc). Instytut Meteorologii i Gospodarki Wodnej Państwowy Instytut Badawczy, Warszawa, 80 - 97 (in Polish).

Knight C.A., Knight N.C. (2001) Hailstorms [In:] Severe Convective Storms (ed. C.A. Doswell). American Meteorological Society, Boston.

Koźmiński C. (1963) Hail in the area of Poland 1946 - 1955 (Opady gradowe na terenie Polski w latach 1946-1955). Societas Scientiarum Stetinensis. XVII, 2 (in Polish).

Merecki R. (1915) Climatology of Polish territories (Klimatologia Ziem Polskich). Warszawa, 167 (in Polish).

Pilorz W. (2015) Very large hail nowcasting based on radar reflecivity signatures (Nowcasting opadów bardzo dużego gradu na podstawie sygnatur odbiciowości radarowej). Preprints conf. Naukowe, społeczne i prawne aspekty występowania groźnych zjawisk atmosferycznych, Warszawa, 4 (in Polish).

Punge H.J., Bedka K.M., Kunz M., Werner A. (2014) A new physically based stochastic event catalog for hail in Europe. Natural Hazards. 71, DOI 10.1007/s11069-0141161-0

Schuster S.S., Blong R.J., Speer M.S. (2005) A hail climatology of the greater Sydney area and New South Wales, Australia. Int. J. Climatol. 25, 1633 - 1650, DOI: 10.1002/joc. 1199

Sioutas M., Meaden T., Webb J. D. C. (2009) Hail frequency, distribution and intensity in Northern Greece. Atmospheric Research. 93, $526-533, \quad$ DOI: 10.1016/j.atmosres.2008.09.023

Skripniková K., Řezáčová D. (2014) Radarbased hail detection. Atmospheric Research. 144, 175 - 185, DOI: http://dx.doi.org/10.1016/j.atmosres.2013.0 6.002 
Taszarek M., Suwała K. (2015) Large hail in Poland in 2012. Quaestiones Geographicae. 34 (1), 75-84, DOI: 10.1515/quageo-20150007

Twardosz R., Niedźwiedź T., Łupikasza E. (2010) Hailstorms in Cracow and their circulation patterns (1863 - 2008) (Burze gradowe w Krakowie i ich uwarunkowania cyrkulacyjne (1863-2008)). [In:] Water in geographical research (Woda w badaniach geograficznych) (ed. T. Ciupa, R. Suligowski). Uniwersytet HumanistycznoPrzyrodniczy Jana Kochanowskiego w Kielcach, Instytut Geografii, COMPUS. Kielce, 303-331 (in Polish).

Vinet F. (2001) Climatology of hail in France. Atmospheric Research. 56, 309 - 323.

Weisman M.L., Klemp J.B. (1984) The structure and classification of numerically simulated convective storms in directionally-varying wind shears. Monthly Weather Review. 112, 2479 - 2498.

Zhang C., Zhang Q., Wang Y., 2008: Climatology of Hail in China 1961 - 2005. Journal of Applied Meteorology and Climatology, 47, 795 - 804, DOI: 10.1175/2007JAMC1603.1

Zinkiewicz W., Michna E., 1955: Hail falls frequency in Lubelskie region according to physiographic patterns (Częstotliwość występowania gradów w województwie lubelskim w zależności od warunków fizjograficznych). Annales Universitatis Marie Curie-Skłodowska Lublin - Polonia, $\mathrm{X}, 5, \mathrm{~B}$ (in Polish).

European Severe Weather Database. (Website accessed: January, 2015 http://www.eswd.eu/). 